\title{
EFFECT OF PUTRESCINE AND UNICONAZOLE ON SOME VEGETATIVE GROWTH, FLOWERING AND CHEMICAL CONSTITUENTS OF Salvia splendens F. PLANT
}

\author{
(Received:13.5.2012)
}

\author{
By \\ S.H. El-Hanafy, M.M. Kandil ${ }^{*}$ and M.M. El-Sabwah ${ }^{*}$ \\ Department of Ornamental Horticulture, Faculty of Agric., Cairo University, Giza, Egypt. \\ *Department of Ornamental Plants and Woody Trees, National Research Centre, Dokki, Cairo, Egypt.
}

\begin{abstract}
A pot experiment was carried out during 2006-2007 and 2007-2008 seasons at the Ornamental Horticulture Department, Faculty of Agriculture, Cairo University, Giza, Egypt and laboratories of the National Research Centre, Dokki, Cairo. The aim of this work was to study the effect of foliar spraying of putrescine at the concentrations of $(0,50,100$ and $150 \mathrm{ppm})$ and uniconazole at the concentrations of $(0$, 10,15 and $20 \mathrm{ppm}$ ) and their interaction on vegetative growth and chemical constituents of Salvia splendens F. plant. Most criteria of vegetative growth expressed as plant height, stem diameter, number of leaves/plant, fresh and dry weights of leaves and stems, and flowering characteristics expressed as number of spikes/plant, were significantly affected by the two growth bioregulators. Putrescine at the concentration of $150 \mathrm{ppm}$ was the most effective in increasing plant height, stem diameter, number of leaves/plant, fresh and dry weights of leaves and stems and number of spikes/plant. Uniconazole at the concentration of $10 \mathrm{ppm}$ increased significantly all the vegetative growth and flowering characters except stem diameter which increased by using $20 \mathrm{ppm}$ uniconazole. The combined treatment of putrescine at $150 \mathrm{ppm}+10 \mathrm{ppm}$ uniconazole produced the highest values of the number of leaves, fresh and dry weights of leaves and stems, also putrescine at $150 \mathrm{ppm}+20 \mathrm{ppm}$ uniconazole gave the highest value of stem diameter. The highest values in the number of spikes/plant were found when the plants were treated with $150 \mathrm{ppm}$ putrescine $+10 \mathrm{ppm}$ uniconazole in the $1^{\text {st }}$ season and plants treated with $100 \mathrm{ppm}$ putrescine $+10 \mathrm{ppm}$ uniconazole in the $2^{\text {nd }}$ season. The content of $\mathrm{N}, \mathrm{P}$ and $\mathrm{K}$ recorded the highest values when plants were treated with $150 \mathrm{ppm}$ putrescine. Uniconazole at $10 \mathrm{ppm}$ gave the highest values in $\mathrm{N} \%, \mathrm{P} \%$, while uniconazole at $15 \mathrm{ppm}$ gave the highest values of $\mathrm{K} \%$. Concerning the interaction between putrescine and uniconazole the results revealed that the plants treated with putrescine at $150 \mathrm{ppm}$ + uniconazole at $10 \mathrm{ppm}$ gave the highest values of $\mathrm{N} \%$ and $\mathrm{P} \%$, while the plants treated with putrescine at $150 \mathrm{ppm}+$ uniconazole at $15 \mathrm{ppm}$ gave the highest values of $\mathrm{K} \%$.
\end{abstract}

Key words: mineral content, putrescine, Salvia splendens F., uniconazole, vegetative growth.

\section{INTRODUCTION}

Salvia splendens are considered as the most important flowering herbaceous plants. They are famous for their beautiful spikes which have various colors as red, purple, pink, salmon, or bicolor flowers, as well as some species of this genus are planted for extracting volatile oils and some medical components. For that, this genus is called "Salvia", which designates from the Latin name "Salvare" which means "to be saved". This genus belongs to family "Lamiaceae" which is known by its aromatic and medicinal plants.

Polyamines possess diverse biological functions and are formed during metabolic processes in living organisms. Polyamines in plants are involved in many steps of protein synthesis, embryogenesis, transcription of genes, cell division, organ development, fruit ripening, leaf senescence, tuber dormancy and stress minimization of plant organs. Moreover, there is a strong association between polyamine metabolism in plants and environmental stress, e.g., nutrient deficiency, drought, soil salinity or temperature stress. Putrescine concentration increases in plants in response to a number of stress factors including water stress, acid treatment, mineral deficiency, and osmotic shock or $\mathrm{CO}_{2}$ treatment (Kosson and Prang, 2005). 
Uniconazole is one of triazole plant growth regulators having important role in crop production, manipulation of plant growth and to yield and induce a variety of morphological and biochemical responses in plants (Fletcher and Hofstra, 1988).

All triazole compounds, its derivatives act as antigibberellin i.e., interfere with the biosynthesis of endogenous gibberellins by preventing the oxidation of entkauren to entkaureonic acid, (Izumi et al., 1988).

Therefore, the work embodied in this experiment was planned to study the effect of putrescine and uniconazole and their interaction on some vegetative growth, flowering characteristics and chemical constituents of Salvia splendens $\mathrm{F}$. plant.

\section{MATERIALS AND METHODS}

The experimental trial was consummated throughout two successive seasons (2006/2007 and 2007/2008) at the nursery of the Ornamental Horticultural Department, Faculty of Agriculture, Cairo University, Giza, Egypt and the laboratories of the National Research Centre, Dokki, Cairo, Egypt. The aim of this work was to study the effect of foliar spraying with different levels of putrescine and uniconazole and their interaction on the vegetative growth and chemical constituents of Salvia splendens F. plant.

Salvia splendens F. seeds were obtained from the Department of Horticulture Plants, Ministry of Agriculture, Giza, Egypt.

The seeds were cultured in plastic trays on the $1^{\text {st }}$ of August 2006 and 2007. Seedlings $(10 \mathrm{~cm}$ in length with 2 pairs of leaves) were individually transplanted on the $1^{\text {st }}$ of September in both seasons in a plastic pot $(30 \mathrm{~cm}$ diameter $)$ filled with $3 \mathrm{Kg}$ mixture of silt and sand $(1: 1 \mathrm{v} / \mathrm{v})$. The layout of the experiment was a complete randomized block design.

When the seedling height attained $15 \mathrm{~cm}$ and had about 10-15 leaves, they were sprayed with the two growth regulators; putrescine (Put) at the concentrations of $(50,100$ and $150 \mathrm{ppm})$, uniconazole (Uni) at the concentrations of $(10,15$ and $20 \mathrm{ppm}$ ) and combination between them, while the control plants were sprayed with distilled water. Fifteen treatments plus control were carried out, each treatment had three replicates and each replicate contained five plants. The plants were sprayed again after one month from the first spray. During the two seasons, the following data were recorded:

\subsection{Measurements of growth parameters}

Plant height $(\mathrm{cm})$, stem diameter $(\mathrm{cm})$, number of leaves/plant, fresh weight of leaves/plant $(\mathrm{g})$, dry weight of leaves/plant $(\mathrm{g})$, fresh weight of stems/plant (g), dry weight of stems/plant (g) and the number of spikes/plant.

2.2. NPK determination: Elements extraction was made using a known weight of the dried shoot samples $(0.5 \mathrm{~g})$. The wet digestion procedure was performed (Piper, 1950). Nitrogen contents were determined by the modified Kjeldahl method as described by Cottenie et al. (1982), phosphorus content was estimated using ammonium molybdate method according to Snell and Snell (1949) and potassium content was measured in the digested solution by flame photometer according to Chapman and Pratt (1961) and the results were represented as g/100g D.W. of plant.

\subsection{Statistical analysis}

Data on vegetative growth and some chemical constituents in the two seasons were statistically analyzed as described by Snedecor and Cochran (1980). Means of all characters were compared by L.S.D test at 0.05 level of significance.

\section{RESULTS AND DISCUSSION \\ 3.1. Vegetative growth 3.1.1. Plant height}

The data recorded in Table (1) show that foliar application of putrescine at the concentrations of 50, 100 and $150 \mathrm{ppm}$ on Salvia splendens significantly increased plant height, giving the values of 49.33, 61.08 and $61.33 \mathrm{~cm}$, respectively, compared to the untreated plants $(38.83 \mathrm{~cm})$ through the $1^{\text {st }}$ season, the same trend was found in the $2^{\text {nd }}$ one. These results are in agreement with those obtained by many investigators, i.e. Youssef et al. (2004) on Matthiola incana, Talaat et al. (2005) on Catharanthus roseus, Mahgoub et al. (2006) on carnation, El-Quesni et al. (2007) on Bougainvillea glabra, El-Sayed (2009) on Chrysanthemum indicum, Mahgoub et al. (2011) on Dahlia pinnata and Youssef (2011) on Populus sp. Polyamines are recognized as a new class of plant growth bioregulators causing increases in shoot growth which might be due to enhancement of cell division activity.

On the other hand, using uniconazole at the concentrations of 10,15 and $20 \mathrm{ppm}$ significantly decreased plant height in most cases in all the applications, giving the values of 53.33, 50.50 and $49.33 \mathrm{~cm}$, respectively, compared with the untreated plants which recorded $57.42 \mathrm{~cm}$ in the $1^{\text {st }}$ season, a similar trend was found in the $2^{\text {nd }}$ one. The results are in accordance with those found by Mahgoub et al. (2006) on Calendula officinalis, 
Table (1): Effect of putrescine and uniconazole on the vegetative growth and flowering of Salvia splendens $\mathrm{F}$. plants during 2006/2007 and 2007/2008 seasons.

\begin{tabular}{|c|c|c|c|c|c|c|c|c|}
\hline \multirow[t]{2}{*}{ Measurements } & \multicolumn{2}{|c|}{ Plant height $(\mathrm{cm})$} & \multicolumn{2}{|c|}{$\begin{array}{c}\text { Stem diameter } \\
(\mathbf{c m})\end{array}$} & \multicolumn{2}{|c|}{$\begin{array}{c}\text { No. of } \\
\text { leaves/plant }\end{array}$} & \multicolumn{2}{|c|}{$\begin{array}{c}\text { No. of } \\
\text { spikes/plant }\end{array}$} \\
\hline & $\begin{array}{c}\mathbf{1}^{\text {st }} \\
\text { season }\end{array}$ & $\begin{array}{c}2^{\text {nd }} \\
\text { season }\end{array}$ & $\begin{array}{c}\mathbf{1}^{s t} \\
\text { season } \\
\end{array}$ & $\begin{array}{c}\text { 2nd } \\
\text { season } \\
\end{array}$ & $\begin{array}{c}1^{s t} \\
\text { season }\end{array}$ & $\begin{array}{c}2^{\text {nd }} \\
\text { season }\end{array}$ & $\begin{array}{c}\mathbf{1}^{s t} \\
\text { season } \\
\end{array}$ & $\begin{array}{c}2^{\text {nd }} \\
\text { season } \\
\end{array}$ \\
\hline \multicolumn{9}{|c|}{ Effect of Putrescine } \\
\hline Put. 0 & 38.83 & 42.17 & 0.74 & 0.90 & 169.00 & 430.25 & 11.83 & 16.17 \\
\hline Put. 50 ppm & 49.33 & 51.25 & 0.81 & 0.97 & 230.25 & 475.00 & 19.92 & 24.17 \\
\hline Put. 100 ppm & 61.08 & 65.58 & 0.88 & 1.03 & 360.08 & 657.58 & 28.08 & 33.92 \\
\hline Put. 150 ppm & 61.33 & 66.50 & 0.99 & 1.11 & 352.42 & 644.58 & 29.50 & 33.17 \\
\hline $\mathbf{L S D}_{0.05}$ & 1.33 & 2.24 & 0.08 & 0.08 & 14.86 & 25.78 & 1.61 & 1.28 \\
\hline \multicolumn{9}{|c|}{ Effect of Uniconazole } \\
\hline Uni. 0 & 57.42 & 62.58 & 0.70 & 0.86 & 247.75 & 511.83 & 20.25 & 22.25 \\
\hline Uni. 10 ppm & 53.33 & 56.92 & 0.78 & 0.92 & 314.25 & 619.58 & 26.58 & 32.25 \\
\hline Uni. 15 ppm & 50.50 & 53.17 & 0.93 & 1.07 & 288.17 & 559.50 & 22.50 & 27.50 \\
\hline Uni. 20 ppm & 49.33 & 52.83 & 1.02 & 1.16 & 261.58 & 516.76 & 20.00 & 25.42 \\
\hline $\mathbf{L S D}_{0.05}$ & 1.33 & 2.24 & 0.08 & 0.08 & 14.86 & 25.78 & 1.61 & 1.28 \\
\hline \multicolumn{9}{|c|}{ Effect of interaction } \\
\hline Put. 0 + Uni. o & 40.33 & 41.67 & 0.60 & 0.77 & 163.00 & 425.00 & 8.67 & 12.00 \\
\hline Put. 0 + Uni. 10 ppm & 39.00 & 42.33 & 0.63 & 0.80 & 176.67 & 456.33 & 15.33 & 19.33 \\
\hline Put. 0 + Uni. 15 ppm & 43.67 & 40.67 & 0.80 & 0.97 & 169.00 & 440.00 & 12.67 & 18.00 \\
\hline Put. o + Uni. 20 ppm & 32.33 & 44.00 & 0.93 & 1.07 & 167.33 & 399.67 & 10.67 & 15.33 \\
\hline Put. 50 ppm + Uni. o & 50.33 & 53.00 & 0.67 & 0.83 & 265.67 & 373.33 & 23.33 & 24.00 \\
\hline Put. 50 ppm + Uni. 10 ppm & 48.67 & 50.00 & 0.73 & 0.93 & 243.00 & 518.67 & 21.00 & 29.00 \\
\hline Put. 50 ppm + Uni. 15 ppm & 51.00 & 47.33 & 0.87 & 1.00 & 215.67 & 470.67 & 18.00 & 21.67 \\
\hline Put. 50 ppm + Uni. 20 ppm & 47.33 & 54.67 & 0.97 & 1.10 & 196.67 & 537.67 & 17.33 & 22.00 \\
\hline Put. 100 ppm + Uni. o & 65.67 & 76.33 & 0.70 & 0.87 & 273.00 & 634.83 & 24.00 & 26.33 \\
\hline Put. 100 ppm + Uni. 10 ppm & 63.00 & 65.67 & 0.73 & 0.90 & 414.67 & 714.33 & 33.67 & 41.67 \\
\hline Put. 100 ppm + Uni. 15 ppm & 53.67 & 65.00 & 1.00 & 1.13 & 397.00 & 681.00 & 28.00 & 36.33 \\
\hline Put. 100 ppm + Uni. 20 ppm & 62.00 & 55.33 & 1.07 & 1.20 & 355.67 & 548.68 & 26.67 & 31.33 \\
\hline Put. 150 ppm + Uni. o & 73.33 & 79.33 & 0.83 & 0.97 & 289.33 & 614.67 & 25.00 & 26.67 \\
\hline Put. 150 ppm + Uni. 10 ppm & 62.67 & 69.67 & 1.00 & 1.03 & 422.67 & 789.00 & 36.33 & 39.00 \\
\hline Put. 150 ppm + Uni. 15 ppm & 53.67 & 59.67 & 1.03 & 1.17 & 371.00 & 646.33 & 31.33 & 34.00 \\
\hline Put. 150 ppm + Uni. 20 ppm & 55.67 & 57.33 & 1.10 & 1.27 & 326.67 & 581.00 & 25.33 & 33.00 \\
\hline $\mathrm{LSD}_{0.05}$ & 2.66 & 4.48 & $\mathbf{0 . 1 6}$ & $\mathbf{0 . 1 7}$ & 29.71 & $\mathbf{5 1 . 5 7}$ & 3.21 & 2.55 \\
\hline
\end{tabular}

Putrescine: Put., Uniconazole: Uni.

El-Quesni et al. (2007) on Bougainvillea glabra, El-Sayed (2009) on Chrysanthemum indicum, Bekheta et al. (2008) on Gerbera jamesonii and El-Sayed (2011) on Schefflera arboricola plants. They found that the application of uniconazole caused a reduction in plant height. In this concern, Cosgrove and Sovonik-Dunford (1989) stated that uniconazole reduced wall relaxation, so growth retardation was affected via a reduction in the wall yield coefficient.

Concerning the interaction between putrescine and uniconazole at different concentrations, the data in Table (1) show that the plants treated with putrescine at the concentration of $150 \mathrm{ppm}$ alone produced the tallest height $(73.33$ and $79.33 \mathrm{~cm})$ in the $1^{\text {st }}$ and the $2^{\text {nd }}$ seasons, respectively, followed by the plants treated with $100 \mathrm{ppm}$ putrescine, giving $(65.67$ and $76.33 \mathrm{~cm})$ in the $1^{\text {st }}$ and the $2^{\text {nd }}$ seasons, respectively, compared with plants treated with $100 \mathrm{ppm}$ putrescine +10 ppm uniconazole giving $(63$ and $65.67 \mathrm{~cm}$ ) in the $1^{\text {st }}$ and the $2^{\text {nd }}$ seasons, respectively.

\subsubsection{Stem diameter}

The data presented in Table (1) indicate that spraying Salvia splendens at different concentrations of putrescine significantly increased stem diameter compared to the control. Using putrescine at the concentration of $150 \mathrm{ppm}$ produced the thickest stems $(0.99$ and $1.11 \mathrm{~cm})$ in the $1^{\text {st }}$ and the $2^{\text {nd }}$ seasons, respectively, compared to the untreated plants which had the thinnest stems $(0.74$ and $0.90 \mathrm{~cm})$ in the $1^{\text {st }}$ and the $2^{\text {nd }}$ seasons, respectively. These results are in agreement with those obtained by El-Quesni $e t$ al. (2010) on Syngonium podophyllum L. Polyamines 
have been implicated in a wide range of biological processes including growth development, cell division and differentiation (Kuehn and Phillips, 2005).

In the case of spraying uniconazole, the data revealed that all concentrations recorded significant increases in stem diameter compared to the untreated plants. The best results were found when the plants were treated with $20 \mathrm{ppm}$ uniconazole. The mean values were 1.02 and 1.16 $\mathrm{cm}$ in the $1^{\text {st }}$ and the $2^{\text {nd }}$ seasons, respectively, compared to the untreated plants $(0.70$ and 0.86 $\mathrm{cm}$ in the $1^{\text {st }}$ and the $2^{\text {nd }}$ seasons, respectively). These results are in the line with those obtained by Mansuroglu et al. (2009) on Consolida orientalis who found that using uniconazle at different concentrations increased stem diameter than the control plants. The increases of stem diameter were directly in relation to the concentration of uniconazole.

The interaction between putrescine and uniconazole show that, $150 \mathrm{ppm}$ putrescine +20 ppm uniconazole produced the thickest stem (1.10 and $1.27 \mathrm{~cm}$ ) in the $1^{\text {st }}$ and the $2^{\text {nd }}$ seasons, respectively, compared to the other treatments, while the thinnest stem was recorded when the plants were treated with Putrescine $0 \mathrm{ppm}+10$ ppm uniconazole, the mean values were 0.63 and $0.80 \mathrm{~cm}$ in the $1^{\text {st }}$ and the $2^{\text {nd }}$ seasons, respectively.

\subsubsection{Number of leaves/plant}

The results in Table (1) indicate that treating Salvia splendens with different concentrations of putrescine increased significantly the number of leaves/plant than untreated plants. Putrescine at the concentration of $100 \mathrm{ppm}$ produced the highest values (360.08 and 657.75) in the $1^{\text {st }}$ and the $2^{\text {nd }}$ seasons, respectively, compared to the other two concentrations. These results are in accordance with those found by Youssef et al. (2004) on Matthiola incana, El-Quesni et al. (2007) on Bougainvillea glabra, El-Tohamy et al. (2008) on Solanum melongena, El-Sayed (2009) on Chrysanthemum indicum, El-Quesni et al. (2010) on Syngonium podophyllum and Mahgoub et al. (2011) on Dahlia pinnata. They found that putrescine with different concentrations increased the number of leaves/plant.

Regarding the effect of uniconazole on the number of leaves/plant, the data revealed that all concentrations significantly increased this character as compared to the control plants. The number of leaves/plant decreased as the concentration of uniconazole was raised, the highest values were found when the plants were treated with $10 \mathrm{ppm}$ uniconazole giving (314.25 and 619.58) in the $1^{\text {st }}$ and the $2^{\text {nd }}$ seasons, respectively, compared with the control plants giving (247.75 and 511.83). These results are in agreement with those obtained by El-Quesni et al. (2007) on Bougainvillea glabra plants, Bekheta et al. (2008) on Gerbera jamesonii and El-Sayed (2009) on Chrysanthemum indicum plants. The increase in leaf formation due to the application of uniconazole may be attributed to the high level of cytokinins (Singh and Bist, 2003).

For the interaction between putrescine and uniconazole, the data show that the treatment of putrescine at $150 \mathrm{ppm}+$ uniconazole at $10 \mathrm{ppm}$ significantly increased the number of leaves/plant giving 422.67 and 789.00 leaves/plant in the $1^{\text {st }}$ and the $2^{\text {nd }}$ seasons, respectively compared to the other interactions and to the control plants.

\subsubsection{Fresh and dry weights of leaves/plant (g)}

The results found in Table (2) show that the foliar spray of putrescine at the different concentrations significantly increased the fresh and dry weights of the leaves/plant in the $1^{\text {st }}$ and the $2^{\text {nd }}$ seasons. Treating the plants with $150 \mathrm{ppm}$ putrescine resulted in the highest increase in fresh weight of leaves/plant (68.44 and $134.47 \mathrm{~g}$ ) in the $1^{s t}$ and the $2^{\text {nd }}$ seasons, respectively, also in dry weight of leaves/plant (19.89 and $36.60 \mathrm{~g}$ ) in the $1^{s t}$ and the $2^{\text {nd }}$ seasons, respectively. These results are in agreement with those obtained by Youssef et al. (2004) on Matthiola incana L., Talaat et al. (2005) on Catharanthus roseus L., Mahgoub et al. (2006) on Dianthus caryophyllus L., El-Sayed (2009) on Chrysanthemum indicum L., El-Quesni et al. (2010) on Syngonium podophyllum L., and Mahgoub et al. (2011) on Dahlia pinnata L. Polyamines exhibit their effect on growth through enhancing cell division and expansion (Cohen, 1998) and they can also act as a source of nitrogen, which stimulates growth (Smith, 1982).

Concerning the effect of uniconazole, the data in Table (2) show that the plants treated with 10 ppm and 15 ppm uniconazole had the significant increases in fresh and dry weights of leaves/plant compared to the untreated plants. The obtained values were 57.82 and $114.03 \mathrm{~g}$ fresh weight in the $1^{\text {st }}$ and the $2^{\text {nd }}$ seasons, respectively, and 16.42 and $30.19 \mathrm{~g}$ dry weight in the $1^{\text {st }}$ and the $2^{\text {nd }}$ seasons, respectively. These results are similar to those obtained by Wang et al. (1990) on three bedding plants including Salvia splendens, Keever and Foster (1991) on some bedding plants which included Salvia farinacea, Kandil and Eleiwa (2008) on Ammi majus L. plants, Bekheta et al. (2008) on Gerbera jamesonii L. plants and ElSayed (2009) on Chrysanthemum indicum L.. 
plants.

By reference to Table (2), the results indicate that the highest values obtained from the interaction between putrescine and uniconazole were found in the plants treated with $150 \mathrm{ppm}$ putrescine $+10 \mathrm{ppm}$ uniconazole in fresh leaves/plant (93.32 and $167.25 \mathrm{~g}$ ) and dry weight of leaves/plant (27.99 and $46.83 \mathrm{~g})$ in the $1^{\text {st }}$ and the $2^{\text {nd }}$ seasons, respectively.

\subsubsection{Fresh and dry weights of stems/plant (g)}

The data presented in Table (2) show that foliar spray of putrescine at different concentrations significantly increased the fresh and dry weight of the stems/plant in the two seasons. Treating the plants with $150 \mathrm{ppm}$ caused the highest increase in fresh weight of stems/plant (92.97 and $227.80 \mathrm{~g}$ ) and dry weight of stems/plant (31.62 and $71.20 \mathrm{~g}$ ) in the $1^{s t}$ and the $2^{\text {nd }}$ seasons, respectively. These results are in accordance with those obtained by
Youssef et al. (2004) on Matthiola incana L., Talaat et al. (2005) on Catharanthus roseus L., Mahgoub et al. (2006) on Dianthus caryophyllus L. plants, El-Sayed (2009) on Chrysanthemum indicum L. and Mahgoub et al. (2011) on Dahlia pinnata L. Polyamines have been described showing various roles such as a new class of plant growth regulators, Hormonal Second Messengers (HSM) and one of the reserves of carbon and nitrogen at least in cultured tissue. At cellular $\mathrm{pH}$ values, these compounds behave as cations and can interact with anionic macromolecules such as DNA, RNA phospholipids and certain proteins. (Hepy and Persson, 1990).

In regarding to using uniconazole, the data in Table (2) show that the plants treated with 10 and $15 \mathrm{ppm}$ uniconazole had the significant increases in fresh and dry weight of stems/plant compared to untreated plants. The highest values of the fresh

Table (2): Effect of putrescine and uniconazole on the vegetative growth of Salvia splendens $\mathbf{F}$. plant during 2006/2007 and 2007/2008 seasons.

\begin{tabular}{|c|c|c|c|c|c|c|c|c|}
\hline \multirow{2}{*}{$\begin{array}{l}\text { Measurements } \\
\text { Treatments }\end{array}$} & \multicolumn{2}{|c|}{$\begin{array}{c}\text { F.W leaves/plant } \\
\text { (g) }\end{array}$} & \multicolumn{2}{|c|}{$\begin{array}{c}\text { F.W. stems/plant } \\
(\mathrm{g})\end{array}$} & \multicolumn{2}{|c|}{$\begin{array}{c}\text { D.W. } \\
\text { leaves/plant (g) }\end{array}$} & \multicolumn{2}{|c|}{$\begin{array}{c}\text { D.W. } \\
\text { stems/plant (g) }\end{array}$} \\
\hline & $\begin{array}{c}1^{s t} \\
\text { season }\end{array}$ & $\begin{array}{c}2^{\text {nd }} \\
\text { season }\end{array}$ & $\begin{array}{c}1^{s t} \\
\text { season }\end{array}$ & $\begin{array}{c}\text { 2nd } \\
\text { season }\end{array}$ & $\begin{array}{c}1^{\text {st }} \\
\text { season }\end{array}$ & $\begin{array}{c}2^{\text {nd }} \\
\text { season }\end{array}$ & $\begin{array}{c}1^{\text {st }} \\
\text { season }\end{array}$ & $\begin{array}{c}2^{\text {nd }} \\
\text { season }\end{array}$ \\
\hline \multicolumn{9}{|c|}{ Effect of Putrescine } \\
\hline Put. 0 & 29.51 & 63.70 & 29.32 & 93.79 & 7.12 & 14.80 & 8.70 & 24.50 \\
\hline Put. 50 ppm & 35.91 & 86.80 & 53.63 & 138.97 & 9.34 & 21.47 & 16.87 & 38.31 \\
\hline Put. 100 ppm & 58.68 & 117.14 & 83.76 & 207.49 & 16.59 & 31.11 & 27.97 & 62.48 \\
\hline Put. 150 ppm & 68.44 & 134.47 & 92.97 & 227.80 & 19.89 & 36.60 & 31.62 & 71.20 \\
\hline $\mathrm{LSD}_{0.05}$ & 2.40 & 3.65 & 1.93 & 2.74 & 0.43 & 0.31 & 0.21 & 0.09 \\
\hline \multicolumn{9}{|c|}{ Effect of Uniconazole } \\
\hline Uni. 0 & 41.14 & 90.54 & 59.81 & 158.24 & 10.82 & 22.85 & 19.11 & 45.26 \\
\hline Uni. 10 & 57.82 & 114.03 & 77.35 & 192.66 & 16.42 & 30.19 & 26.06 & 59.67 \\
\hline Uni. 15 ppm & 51.62 & 106.74 & 64.37 & 169.20 & 14.45 & 28.00 & 21.09 & 50.00 \\
\hline Uni. 20 ppm & 41.96 & 90.80 & 58.15 & 147.95 & 11.25 & 22.95 & 18.89 & 41.57 \\
\hline $\operatorname{LSD}_{0.05}$ & 2.40 & 3.65 & 1.93 & 2.74 & 0.43 & 0.31 & 0.21 & 0.09 \\
\hline \multicolumn{9}{|c|}{ Effect of interaction } \\
\hline Put. 0 + Uni. 0 & 28.39 & 60.25 & 25.20 & 90.56 & 6.70 & 12.87 & 7.28 & 23.55 \\
\hline Put. 0 + Uni. 10 & 31.82 & 70.53 & 34.23 & 110.27 & 7.86 & 16.79 & 10.41 & 29.33 \\
\hline Put. 0 + Uni. 15 ppm & 29.03 & 67.09 & 30.02 & 97.12 & 7.03 & 15.70 & 8.95 & 25.45 \\
\hline Put. 0 + Uni. 20 ppm & 28.79 & 56.93 & 27.82 & 77.20 & 6.88 & 13.85 & 8.15 & 19.69 \\
\hline Put. 50 ppm + Uni. o & 43.18 & 77.38 & 66.32 & 121.76 & 11.44 & 24.67 & 21.22 & 32.88 \\
\hline Put. 50 ppm + Uni. 10 ppm & 33.17 & 82.92 & 58.34 & 142.87 & 8.59 & 20.32 & 18.38 & 39.57 \\
\hline Put. 50 ppm + Uni. 15 ppm & 34.63 & 89.00 & 49.38 & 130.69 & 9.07 & 22.25 & 15.36 & 35.68 \\
\hline Put. 50 ppm + Uni. 20 ppm & 32.65 & 97.90 & 40.46 & 160.56 & 8.26 & 18.65 & 12.50 & 45.12 \\
\hline Put. 100 ppm + Uni. 0 & 45.62 & 110.71 & 70.33 & 195.82 & 12.27 & 26.20 & 22.65 & 57.18 \\
\hline Put. 100 ppm + Uni. 10 ppm & 72.98 & 135.41 & 103.12 & 250.07 & 21.24 & 36.83 & 35.68 & 81.52 \\
\hline Put. 100 ppm + Uni. 15 ppm & 65.65 & 120.47 & 83.27 & 210.91 & 18.84 & 32.53 & 27.73 & 62.22 \\
\hline Put. 100 ppm + Uni. 20 ppm & 50.48 & 101.95 & 78.31 & 173.16 & 14.03 & 28.90 & 25.84 & 49.00 \\
\hline Put. 150 ppm + Uni. 0 & 47.36 & 113.81 & 77.38 & 224.80 & 12.88 & 27.66 & 25.30 & 67.44 \\
\hline Put. 150 ppm + Uni. 10 ppm & 93.32 & 167.25 & 113.68 & 267.42 & 27.99 & 46.83 & 39.79 & 88.25 \\
\hline Put. 150 ppm + Uni. 15 ppm & 77.19 & 150.41 & 94.81 & 238.09 & 22.85 & 41.51 & 32.33 & 76.66 \\
\hline Put. 150 ppm + Uni. 20 ppm & 55.90 & 106.42 & 86.01 & 180.89 & 15.82 & 30.39 & 29.07 & 52.45 \\
\hline $\mathbf{L S D}_{0.05}$ & 4.79 & 7.30 & 3.85 & 5.49 & 0.86 & 0.62 & 0.42 & 0.18 \\
\hline
\end{tabular}

Putrescine: Put., Uniconazole: Uni., Fresh weight: F.W., Dry weight: D.W. 
weight of stems/plant were 77.35 and $192.66 \mathrm{~g}$ and the dry weight of stems/plant were 26.06 and $59.67 \mathrm{~g}$ in the $1^{\text {st }}$ and the $2^{\text {nd }}$ seasons, respectively, when the plants were treated with $10 \mathrm{ppm}$ uniconazole. These results are similar to those obtained by Keever and Foster (1991) on some bedding plants which included Salvia farinacea, Kandil and Eleiwa (2008) on Ammi majus L. and El-Sayed (2009) on Chrysanthemum indicum L.

In Table (2), the results show that the highest values obtained from the interaction between putrescine and uniconazole were found in the plants treated with $150 \mathrm{ppm}$ putrescine $+10 \mathrm{ppm}$ uniconazole in fresh weight of stems/plant (113.68 and $267.42 \mathrm{~g}$ ) and dry weight of stems/plant ( 39.79 and $88.25 \mathrm{~g}$ ) in the $1^{\text {st }}$ and the $2^{\text {nd }}$ seasons, respectively.

\subsection{Flowering characteristics \\ 3.2.1. Number of spikes/plant}

Data presented in Table (1) indicate that foliar spraying of Salvia splendens F. with putrescine at the concentrations of 50,100 and $150 \mathrm{ppm}$ caused significant increase in the number of spikes/plant in both seasons than the control. The highest values were found when the plants were treated with $150 \mathrm{ppm}$ putrescine giving 29.50 and 100 ppm putrescine giving 33.92 compared to the control (11.83 and 16.17) in the $1^{\text {st }}$ and the $2^{\text {nd }}$ seasons, respectively. These findings are in accordance with some investigators i.e., Youssef et al. (2004) on Matthiola incana, Mahgoub et al. (2006) on Dianthus caryophyllus, Abd El-Aziz et al. (2009) on gladiolus and Mahgoub et al. (2011) on dahlia. This may be explained that the conjugated polyamines are known to be associated with the physiology of flowering (Solcum and Galston, 1985).

With regard to the effect of uniconazole, the data indicate that in the $1^{s t}$ season the application of 10 and $15 \mathrm{ppm}$ uniconazole increased the number of spikes/plant than the untreated plants, while the application of 10,15 and $20 \mathrm{ppm}$ uniconazole treatments increased the number of spikes/plant in the second season than the control plants. The highest values were obtained when the plants treated with $10 \mathrm{ppm}$ which recorded 26.58 and 32.25 compared to the control plants giving 20.25 and 22.25 in the $1^{\text {st }}$ and the $2^{\text {nd }}$ seasons, respectively. In support of these results significant influence of uniconazole increasing the number of spikes/plant has been experimentally sustained by Yoo et al. (1999) on Chrysanthemum, Jung et al. (2000) on Chrysanthemum, Mahgoub et al. (2006) on Calendula officinalis, Bekheta et al. on Gerbera jamesonii and El-Sayed (2009) on
Chrysanthemum indicum. It may be due that paclobutrazol, an inhibitor of gibberellins biosynthesis or action significantly accelerate flowering at certain doses in woody, perennial and annual plants, (Karagusel and Ortacesme, 2002).

Regarding the effect of interaction between putrescine and uniconazole, data show that the highest values were found when the plants were treated with $150 \mathrm{ppm}$ putrescine $+10 \mathrm{ppm}$ uniconazole in the $1^{\text {st }}$ season, while the plants treated with $100 \mathrm{ppm}$ putrescine $+10 \mathrm{ppm}$ uniconazole gave the highest values in the $2^{\text {nd }}$ season.

\subsection{Mineral content \\ 3.3.1. Nitrogen percentage in shoot}

The data illustrated in Figs. (1) and (2) indicate significant effect of putrescine and uniconazole on the percentage of nitrogen in Salvia splendens F. It was noticed that the $\mathrm{N} \%$ in the shoots increased by all the tested concentrations of the two used bio-regulators than in the untreated plants.

Concerning the effect of putrescine, the results indicated that treating plants with $150 \mathrm{ppm}$ gave the highest significant values (2.01 and 2.29\% D.W.) in the $1^{\text {st }}$ and the $2^{\text {nd }}$ seasons, respectively, than the untreated plants which recorded (1.27 and $1.55 \%$ D.W.) in the $1^{s t}$ and the $2^{\text {nd }}$ seasons, respectively, followed by $100 \mathrm{ppm}$ putrescine, then $50 \mathrm{ppm}$ putrescine. These results agree with those obtained by El-Quesni et al. (2007) on Bougainivillea glabra plants, El-Sayed (2009) on Chrysanthemum indicum, El-Quesni et al. (2010) on Syngonium podophyllum and Youssef (2011) on Populus sp. They found that the using of putrescine at different concentrations increased $\mathrm{N} \%$ content in the treated plants than in the untreated ones.

In the case of uniconazole, it was found that all tested concentrations increased $\mathrm{N}$ content compared to untreated plants. Plants treated with $10 \mathrm{ppm}$ uniconazole produced the highest values (1.79 and $2.16 \%$ D.W.) compared to the control plants (1.53 and $1.80 \%$ D.W.) in the $1^{\text {st }}$ and the $2^{\text {nd }}$ seasons, respectively. These results are similar to those obtained by El-Quesni et al. (2007) on Bougainvillea glabra, Kandil and Eleiwa (2008) on Ammi majus, Abd-El-Aziz et al. (2009) on gladiolus and El-Sayed (2009) on Chrysanthemum indicum.

Regarding the effect of interaction between putrescine and uniconazole it was found that spraying the plants with $150 \mathrm{ppm}$ putrescine +10 ppm uniconazole recorded the highest $\mathrm{N} \%$ content (2.30 and $2.60 \%$ D.W.) than the control plants (1.19 and $1.42 \%$ D.W.) in the $1^{s t}$ and the $2^{\text {nd }}$ (1.19 

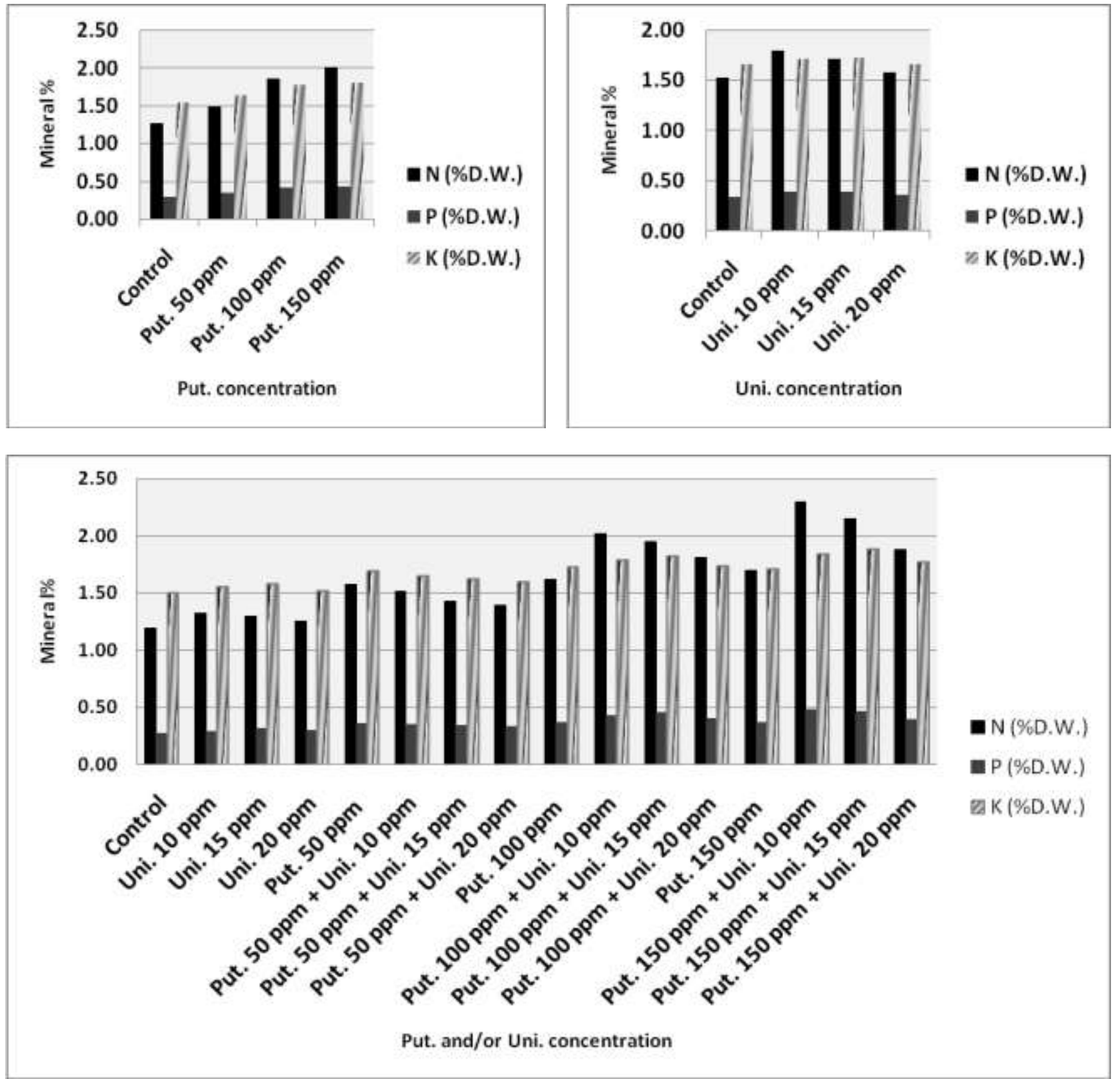

Putrescine: Put., Uniconazole: Uni., Dry weight: D.W.

Fig. (1): Effect of putrescine and uniconazole on nitrogen, phosphorus and potassium in the shoots of Salvia splendens F. during 2006/2007 (first season). 

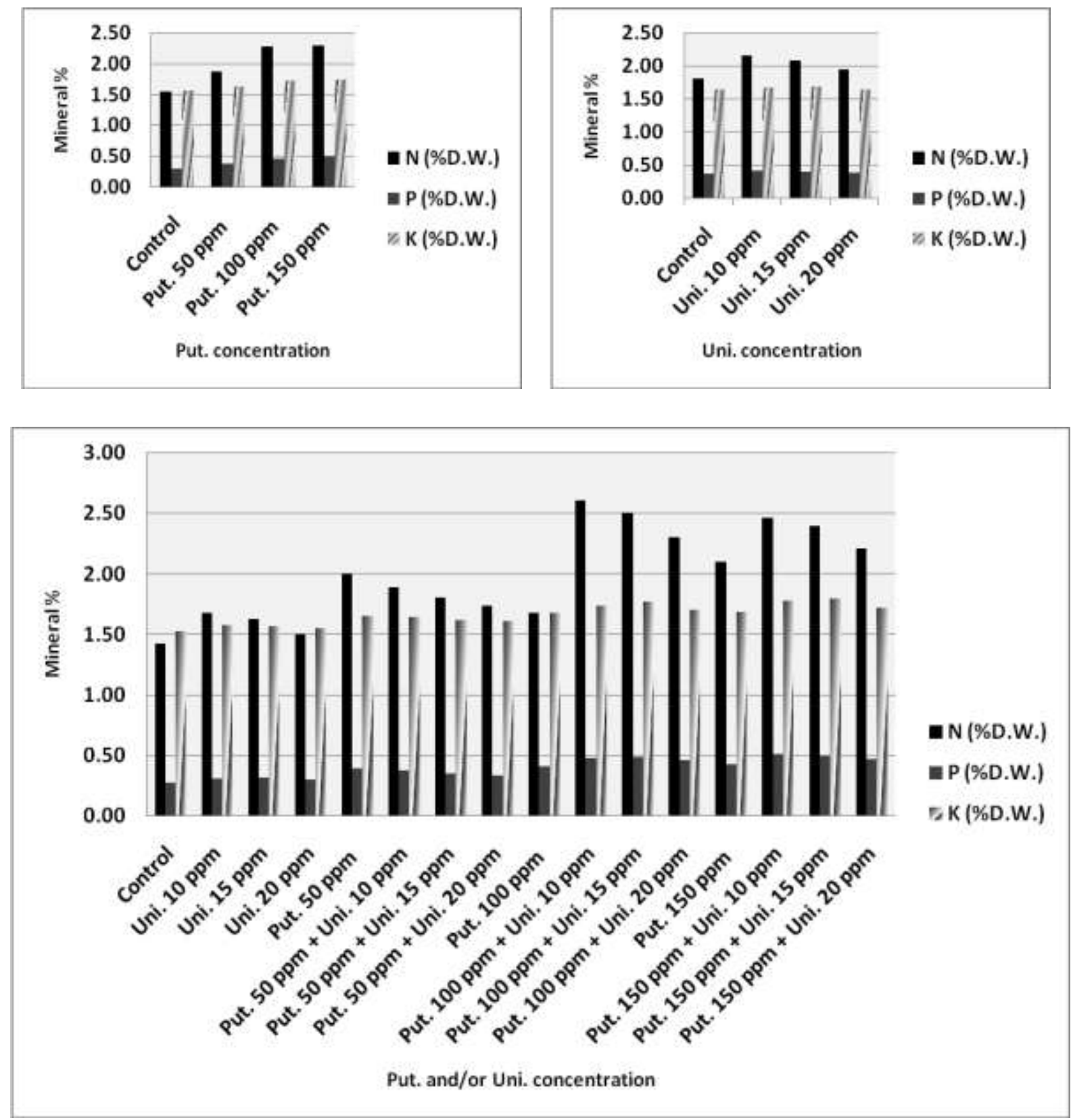

Putrescine: Put., Uniconazole: Uni., Dry weight: D.W.

Fig. (2): Effect of putrescine and uniconazole on nitrogen, phosphorus and potassium in the shoots of Salvia splendens F. during 2007/2008 (second season). 
and $1.42 \%$ D.W.) in the $1^{s t}$ and the $2^{\text {nd }}$ seasons, respectively, while the lowest N\% was obtained with $0 \mathrm{ppm}+15 \mathrm{ppm}$ uniconazole whichrecorded ( 2.15 and $2.50 \%$ D.W.) in the $1^{\text {st }}$ and the $2^{\text {nd }}$ seasons, respectively.

\subsubsection{Phosphorus percentage in shoots}

The data illustrated in Figs. (1) and (2) showed that the application of putrescine at three concentrations produced significant increase in $\mathrm{P} \%$ in shoots than the control plants in the two seasons. The highest values were found when the plants were treated with $150 \mathrm{ppm}$ putrescine giving 0.43 and $0.48 \%$ D.W. in the $1^{s t}$ and the $2^{\text {nd }}$ seasons, respectively.

In the case of uniconazole treatment, the data also showed significant increase in $\mathrm{P} \%$ in the plants were treated with different concentrations of uniconazole. The highest values were found when the plants treated with $10 \mathrm{ppm}$ uniconazole in the $1^{s t}$ and the $2^{\text {nd }}$ seasons, which recorded 0.39 and $0.42 \%$ respectively, than the control plants $(0.34$ and $0.38 \%$ D.W. $)$ in the $1^{\text {st }}$ and the $2^{\text {nd }}$ seasons, respectively.

The plants treated with putrescine at the concentration of $150 \mathrm{ppm}+$ uniconazole at the concentration of $10 \mathrm{ppm}$ produced the highest $\mathrm{P} \%$ values $(0.48$ and $0.51 \%$ D.W. $)$ followed by putrescine $150 \mathrm{ppm}+$ uniconazole $15 \mathrm{ppm}$ which gave 0.46 and $0.50 \%$ D.W. in the $1^{\text {st }}$ and the $2^{\text {nd }}$ seasons, respectively. Whereas the untreated plants gave 0.27 and $0.28 \%$ D.W. in the $1^{s t}$ and the $2^{\text {nd }}$ seasons, respectively.

These results are similar to those obtained by El-Quesni et al. (2007) on Bougainvillea glabra, Kandil and Eleiwa (2008) on Ammi majus, AbdEl-Aziz et al. (2009) on gladiolus plants, El-Sayed (2009) on Chrysanthemum indicum, El-Quesni et al. (2010) on Syngonium podophyllum and Youssef (2011) on Populus sp. They found that foliar application of putrescine and triazole compounds increased $\mathrm{P} \%$ content of the plants.

\subsubsection{Potassium percentage in shoots}

The data illustrated in Figs. (1) and (2) showed significant increase when the plants treated by the three concentrations of putrescine and the best results were found by using $150 \mathrm{ppm}$ putrescine than the untreated plants which recorded 1.80 and $1.75 \%$ D.W. in the $1^{s t}$ and the $2^{n d}$ seasons, respectively. These results are in agreement with El-Quesni et al. (2007) on Bougainvillea glabra, El-Sayed (2009) on Chrysanthemum indicum, ElQuesni et al. (2010) on Syngonium podophyllum and Youssef (2011) on populus. They found that putrescine with different concentrations increased the content of $\mathrm{K} \%$ in the plants.
In the case of the effect of uniconazole, the data revealed that all concentrations gave significant increase in $\mathrm{K} \%$ content. The highest values were found by using $15 \mathrm{ppm}$ uniconazole giving 1.72 and $1.69 \%$ D.W. in the $1^{\text {st }}$ and the $2^{\text {nd }}$ seasons, respectively than the untreated plants (1.66 and $1.64 \%$ D.W.) in the $1^{\text {st }}$ and the $2^{\text {nd }}$ seasons, respectively. These results are similar to those obtained by El-Quesni et al. (2007) on Bougainivillea glabra, Kandil and Eleiwa (2008) on Ammi majus, Abd-El-Aziz et al. (2009) on gladiolus and El-Sayed (2009) on Chrysanthemum.

The combination of putrescine $(150 \mathrm{ppm})$ and uniconazole $(15 \mathrm{ppm})$ resulted in the greatest increase of $\mathrm{K}$ concentration in the shoots in both seasons compared to the control. The recorded values were $1.88 \%$ D.W. in the $1^{\text {st }}$ season compared to $1.50 \%$ D.W. in the control plants and of the $1.80 \%$ D.W. in the $2^{\text {nd }}$ season compared to $1.53 \%$ in the control plants.

The positive obtained results may be due to the main role of bioregulators on growth of roots and consequently increased the absorbing area of the plants (Hanafy et al., 2002). Salama (1999) recorded that polyamines (PAs) as spray increased some nutrient elements particularly $\mathrm{K}$, which was found to serve a vital role in photosynthesis by directly increase growth and photosynthetic pigments, and hence $\mathrm{CO}_{2}$ assimilation. Shawky (2003) reported that the increment in minerals uptake $(\mathrm{N}, \mathrm{P}$ and $\mathrm{K})$ by PAs treatment, the promotive effect of PAs treatment on plant growth productivity as well as on plant chemical composition may be due to the effect on many metabolic and physiological processes. Youssef (2007) noticed that PAs have possibly increased activities on metabolic processes in plant. Accordingly, physiological performance of such plants was improved, as manifested by the increased efficiency of roots in absorbing macronutrients from the soil.

Concerning the effect of uniconazole concentrations on the content of N, P and K; Kuchenbuch and Jung (1988), Bekheta (1993) and ElKadey (2002), found that using different concentrations of uniconazole increased the content of mineral ions in the treated plants (Davies, 1995). Also, the positive obtained results of uniconazole may be due to its main role on the growth of roots and consequently increased the absorbing area for plants.

Recommendation: From this study it may be recommended spraying salvia plants twine with putrescine $150 \mathrm{ppm}$ and Uniconazole $10 \mathrm{ppm}$ to enhance the vegetative growth and the content of NPK as compared with the untreated plants. 


\section{REFERENCES}

Abd El-Aziz N. G., Taha L. S. and Ibrahim S. M. (2009). Some studies on the effect of putrescine, ascorbic acid and thiamine on growth, flowering and some chemical constituents of gladiolus plants at Nubaria. Journal of Applied Sciences, 2 (2): 169-179.

Bekheta M. A., Abbas S., El-Kobisy O. S. and Mahgoub M. H. (2008). Influence of selenium and paclobutrazole on growth, metabolic activities and anatomical characters of Gerbera jamesonii L. Australian Journal of Basic and Basic Applied Sciences, 2 (4): 1284-1297.

Chapman H.D. and Pratt P.F. (1961). Methods of Analysis for Soils, Plants and Water. Div. of Agric. Sci. Univ. of Calif., USA, pp. 309.

Cohen S.S. (1998). A Guide to the polyamines. Oxfored University Press,Oxford.

Cosgrove D. J. and Sovonik- Dunford, S. A. (1989). Mechanism of gibberellin-dependent stem elongation in peas. Plant Physiol., 89: 184-191.

Cottenie A. M., Verloo M., Kiekens L., Velghe G. and Camerlynck, R. (1982). Chemical Analysis of Plant and Soil. Laboratory of Analytical and Agrochemistry. State Univ. Ghent, Belgium, 100-129 pp.

Davies P. J. (1995). The plant hormones: Their nature, occurrence, and functions. In Plant Hormones: Physiology, Biochemistry and Molecular Biology, P. J. Davies, ed., Kluwer, Boston, pp. 13-38.

El-Kadey F. M. A. (2002). Some studies on the effect of growth regulator uniconazole on the growth, some metabolic changes, levels endogenous hormones and productivity of wheat plants. M.Sc. Thesis, Fac. Sci., AlAzhar Univ., Egypt, 138p.

El-Quesni F. E., Kandil M. M. and Mahgoub M. H. (2007). Some studies on the effect of putrescine and paclobutrazole on the growth and chemical composition of Bougainvillea glabra L. at Nubaria. American Eurasian J. Agric.\& Environ. Sci., 2 (5): 552-558.

El Nativo Growers, Inc., California Native Plants/Salvias.

http://www.laspilitas.com/index.htm

El-Quesni F. E., Mahgoub M. H. and Kandil M. M. (2010). Impact of foliar spray of inorganic fertilizer and bioregulator on vegetative growth and chemical composition of Syngonium podophyllum L. plants at Nubaria. Journal of American Science. 6 (8): 288-294.

El-Sayed I. M. (2009). Physiological and biological studies on Chrysanthemum indicum L. M. Sc. Thesis, Fac. Agri., Cairo Univ., Egypt, 132p.
El-Sayed S. M. (2011). Effect of Growing Media and Some Growth Regulators on Growth and Chemical Composition of Schefflera arboricola Plant. M. Sc. Thesis, Fac. Agri., Cairo Univ., Egypt, 152p.

Fletcher R. A. and Hofstra G. (1988). Triazoles as potential plant protectants .In: Berg D and Plempel M (eds) sterol biosynthesis inhibitors. Pharmaceutical and Agricultural Aspects., Cambridge, England: Ellis Hard Wood Ltd pp 321-331.

Hanafy A. H., Gad M. M. A., Hassan H. M. and Amin M. A. (2002). Improving growth and chemical composition of (Myrtus communis) grown under soil salinity conditions by polyamines foliar application. Proc. Minia $1^{\text {st }}$ Conf. for Agric. and Environ. Sci., Minia; Egypt, March 25-28.

Hepy O. and Persson L. (1990). Molecular genetics of polyamine synthesis in eukaryotic cells. Trends Biochem. Sc., (15): 153-158.

Izumi K., Nakagawa S., Kobayashi H., Oshio H., Sakurai A. and Takahashi N. (1988). Levels of IAA, cytokinins, ABA and ethylene in rice plants as affected by gibberellin bioynthesis inhibitor, uniconazole. Plant Cell Physiol., 29 (1): 97-104.

Jung S. S., Jeong H H. and Kim K. S. (2000). Effects of uniconazole treatment on the growth and flowering of potted Chrysanthemum indicum L. Korean J. Hort. Sci. Techn., 18 (1): 28-32.

Kandil H. and Eleiwa M. M. E. (2008). Effect of growth regulator uniconazole and salt stress on growth, yield and nutrient content of Ammi majus L. plant. Australian Journal of Basic and Applied Sciences, 2 (3): 458-465.

Karagusel O. and Ortacesme V. (2002). Influence of paclobutrazol on the growth and flowering of Bougainvillea glabra 'Sanderiana'. Akdeniz Uni. J. Fac. Agr., 15 (1): 79-84.

Keever G.J. and Foster W.J. (1991). Production and postproduction performance of uniconazole-treated bedding plants. Journal of Environmental Horticulture, (9):203-206.

Kosson R. and Prange R.K. (2005): The occurrence, physiological role and nutritive importance of polyamines in vegetables and fruits. Vegetable Crops Research Bulletin. (63): 5-24.

Kuchenbuch R. and Jung J. (1988). Changes in root shoot ratio and ion uptake of maize (Zea mays L.) from soil as influenced by 
plant growth regulators. Plant and Soil, 109: 151-57.

Kuehn G.D. and Phillips G.C. (2005) Role of polyamines in apoptosis and other recent advances in plant polyamines. Crit. Rev. Plant Sci., (24): 123-130.

Mahgoub M. H., El-Ghorab A. H. and Bekheta M. A. (2006). Effect of some bioregulators on the endogenous phytohormones, chemical composition, essential oil and its antioxidant activity of carnation (Dianthus caryophyllus L.) J. Agric. Sci. Mansoura Univ., 31 (7): 4229-4245.

Mahgoub M. H., Abd El-Aziz N. G. and Mazhar A. M. A. (2011). Response of Dhalia pinnata L. plant to foliar spray with putrescine and thiamine on growth, flowering and photosynthetic pigments. American-Eurasian J. Agric. \& Environ. Sci.., 10 (5): 769-775.

Mansuroglu S., Karaguzel O., Ortacesme V. and Soyan M. S. (2009). Effect of paclobutrazol on flowering, leaf and flower color of Consolida orientalis. Pak. J. Bot., 41 (5): 2323-2332.

Piper C. S. (1950). Soil and Plant Analysis. Inter Sci., New York, 368 pp.

Salama-Karima H. A. (1999). Amelioration of salinity effect in wheat plant by polyamines. Ph.D Thesis, Fac. Science, Ain Shams Univ., Egypt, 192p.

Shawky-Neveen B. T. (2003). Physiological studies on the effect of salinity, ascorbic acid and putrescine on sweet pepper plant. $\mathrm{Ph}$. D. Thesis, Fac. Agric., Cairo Univ., Egypt. 141p.

Singh A. K. and Bist L. D. (2003). Effect of paclobutrazol on growth and flowering in rose cv. Gruss- an-Teplitz. Journal of Horticulture. 60 (2): 188-191.

Smith T. A. (1982). The function and metabolism of polyamines in higher plants. In Wareing PE (ed), Plant Growth Substances. P.683. Academic Press, New York.

Snedecor G.W. and Cochran, W.G. (1980). Statistical Methods. $7^{\text {th }}$ ed. Iowa State, Univ. Press, Ames. Iowa, USA.

Snell F. D. and Snell C.T. (1949). Colorimetric Methods of Analysis. $3^{\text {rd }}$ ed. Van Nostrand, New York, USA, pp 785-807.

Solcum R. D. and Galston A. W. (1985). Changes in polyamines associated with post fertilization and development in tobacco ovary tissue. Plant Physiol., 79: 336- 343.

Talaat I. M., Bekheta M. A. and Mahgoub M. H. (2005). Physiological response of periwinkle plants (Catharanthus roseus L.) to tryptophan and putrescine. International Journal of Agriculture and Biology, 7 (2): 210-213.

Wang X., Jiao J. and Tsujita M. J. (1990). Effect of sumagic on growth of three bedding plants. Acta Horticulture. 272, 305-309.

Yoo Y. K., Kang S. W. and Kin H. K. (1999). Effects of pinching an diaminozide treatment on growth and flowering of Chrysanthemum cv. Zaadskii. J. Korean Soc. Agri. Sci., 40(5): 598-602.

Youssef A. A., Mahgoub M. H. and Talaat I. M. (2004). Physiological and biochemical aspects of Matthiola incana plants under the effect of Putrescineand kinetin treatments. Egypt. J. Appl. Sci., 19 (9B): 492-510.

Youssef E. A. E. (2007). Increasing drought tolerance of gladiolus plants through application of some growth regulators. M. Sc. Thesis, Fac. Agric., Zagazig Univ., Egypt. 130 p.

Youssef N. M. (2011). Physiological studies on some Populus species. M. Sc. Thesis, Fac. Agri., Cairo Univ., Egypt, 132p.

$$
\begin{aligned}
& \text { تأثير مادتي البوتريسين واليونيكونازول على بعض الصفات الخضرية } \\
& \text { والزهرية والمكونات الكيماوية لنبات كalvia splendens } \\
& \text { صفية حمدي الحنفي - *ماجدة محروس قنديل -ميادة الصبوة } \\
& \text { قسم بساتين الزينة ـ كلية الزر اعة ـ جامعة القاهرة }
\end{aligned}
$$

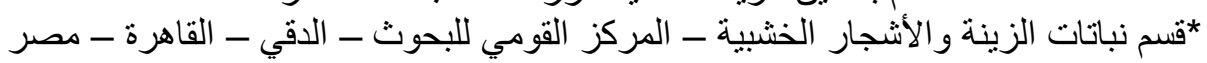

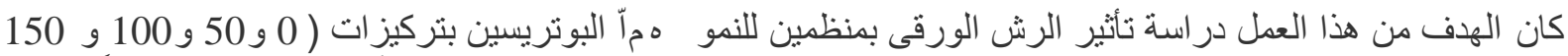

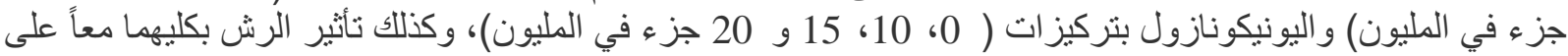

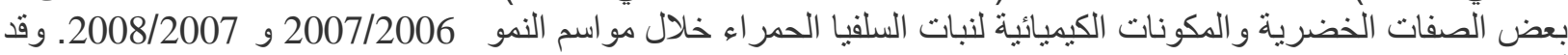
أظهرت النتائج ما يلي: - ت أخطر 
تأثرت معظم الصفات الخضرية مثل طول النبات، وقطر الساق، و عدد الأور اق لكل نبات، و عدد الأفرع لكل نبات،

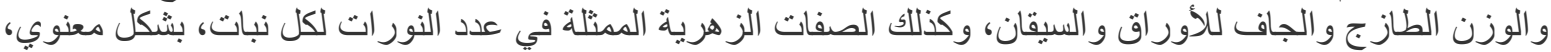

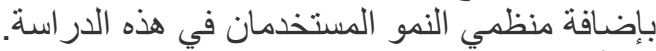
أدى رش ألنباتات بالبوتريسين بتركيز 150 جزء النئ في المليون إلى أعلى زيادة في طول النبات، وقطر الساق، وعدد

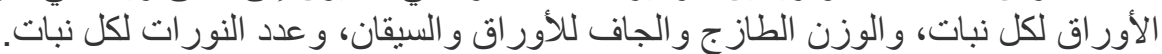

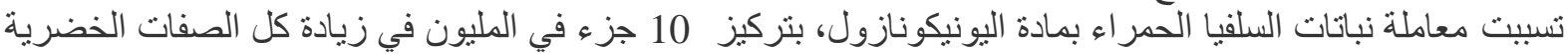

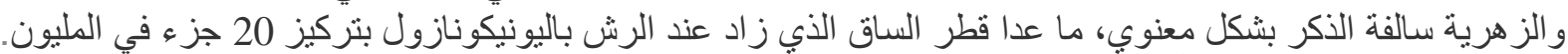

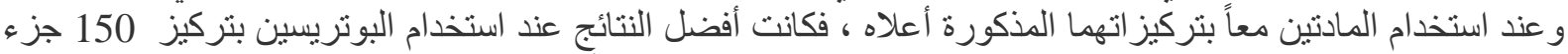

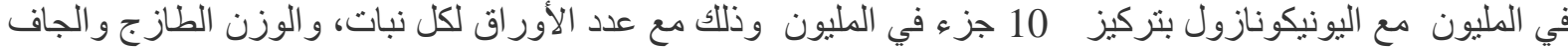

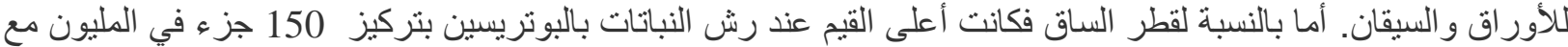

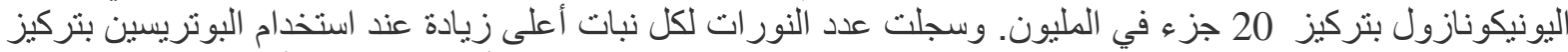

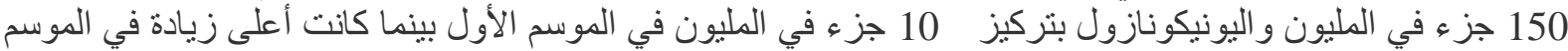

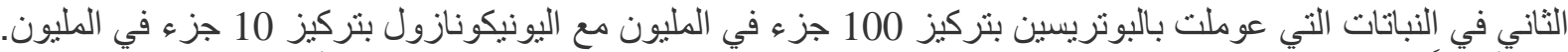

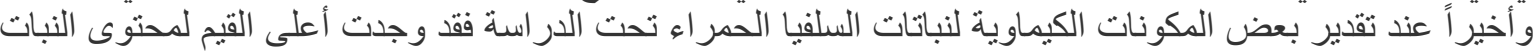

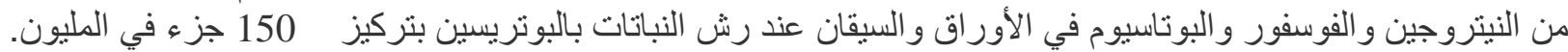

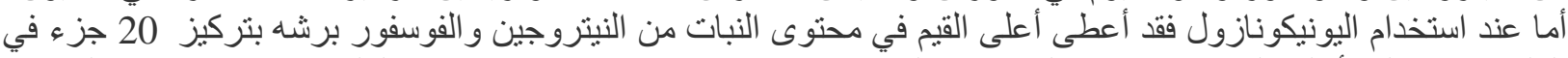

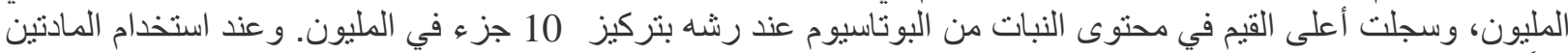

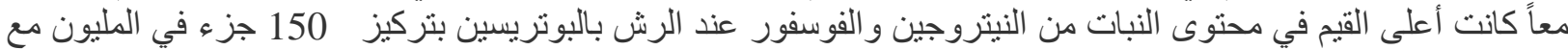

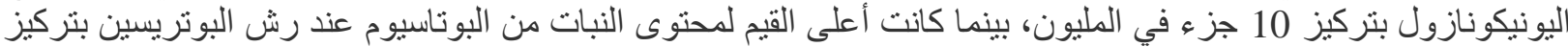

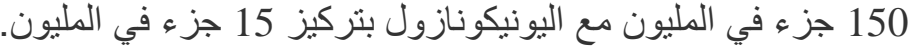

المجلة العلمية لكلية الزراعة - جامعة القاهرة - المجلا (63) العدد الئلث ( يوليو 2012):315-326. 